\title{
Pengukuran Laju Pelepasan Kalor pada Tangki SWH dengan Pipa Berisi Campuran Paraffin Wax dan Serbuk Tembaga 10\% Berat
}

\author{
(Measurement of The Heat Release Rate in a SWH tank With a Pipe Containing a Mixture \\ of Paraffin Wax and Copper Powder of $10 \%$ by Weight) \\ Tito Hadji Agung S. ${ }^{a}$, Sri Hannadhitya Farhan Yustianto ${ }^{b}$ \\ a,b Jurusan Teknik Mesin, Fakultas Teknik, Universitas Muhammadiyah Yogyakarta \\ Jalan Lingkar Selatan Tamantirto, Kasihan, Bantul, DI Yogyakarta, Indonesia, \\ atitohas@yahoo.com, bhanadityafarhan@gmail.com
}

\begin{abstract}
Pada SWH (Solar Water Heater) konvensional, air sebagai media penyimpan panas di tangki. Air memiliki densitas yang besar sehingga konstruksi akan berat dan memerlukan penguatan pada rangka atap. Paraffin wax adalah jenis phase change material (PCM) yang memiliki densitas yang rendah sehingga ringan dan memiliki densitas energi yang besar sehingga dapat menampung energi yang besar untuk volume yang kecil. Namun, paraffin wax memiliki konduktivitas termal yang rendah sehingga perlu ditambahkan serbuk $\mathrm{Cu}$ untuk meningkatkan konduktivitas termalnya. Pada penelitian ini, digunakan campuran paraffin wax dengan serbuk $\mathrm{Cu} 10 \%$ berat. Tujuan penelitian ini adalah mengetahui laju pelepasan kalor air dan campuran PCM. Penelitian ini menggunakan empat variasi debit air, yaitu $1 ; 1,5 ; 2$; dan 2,5 LPM. Penelitian ini dilakukan dengan cara discharging bertahap. Pengambilan data dilakukan mulai pada suhu tangki $70{ }^{\circ} \mathrm{C}$ dan berakhir ketika suhu bak air penampung mencapai $35^{\circ} \mathrm{C}$. Data yang diambil saat proses discharging adalah suhu air pada tangki dan suhu PCM di dalam kapsul di tangki. Laju pelepasan kalor ditentukan dengan perhitungan kalor kumulatif yang dilepaskan oleh air dan campuran PCM serta waktunya. Hasil penelitian menunjukkan bahwa semakin besar debit air, semakin besar pula laju pelepasan kalornya. Laju pelepasan kalor air terbesar sebesar $790 \mathrm{~J} / \mathrm{s}$, sedangkan laju pelepasan kalor oleh campuran PCM dan serbuk Cu sebesar $101,44 \mathrm{~J} / \mathrm{s}$. Dari hasil ini, masih diperlukan penelitian lanjutan dengan persentase serbuk Cu yang lebih besar.
\end{abstract}

Abstrak

Kata kunci: SWH, PCM, paraffin wax, discharging bertahap

\begin{abstract}
In conventional SWH (Solar Water Heater), water is used as a heat storage medium in the tank. Water has a large density, so the construction will be heavy and requires reinforcement on the roof frame. Paraffin wax is a type of phase change material (PCM) with a low density so that it is light and has a large energy density to accommodate large amounts of energy for a small volume. However, paraffin wax has low thermal conductivity, so it is necessary to add $\mathrm{Cu}$ powder to increase its thermal conductivity. In this study, a mixture of paraffin wax and $10 \%$ Cu powder was used. This study aimed to determine the rate of heat release of water and of the PCM mixture. This study uses four water discharge variations, namely 1; 1.5; 2; and 2.5 LPM. Data collection was carried out starting at a tank temperature of $70^{\circ} \mathrm{C}$ and ending when the reservoir water temperature reached $35^{\circ} \mathrm{C}$. During the discharging process, the data taken are the water temperature in the tank and the PCM temperature in the capsule in the tank. Rate of heat released is determined by calculating cumulative heat released by the water dan the mixture of PCM and the total time. The results showed that the greater the water discharge, the greater the rate of heat release. The largest water heat release rate was $790 \mathrm{~J} / \mathrm{s}$, while the heat release rate by a mixture of PCM and $\mathrm{Cu}$ powder was $101.44 \mathrm{~J} / \mathrm{s}$. From these results, further research is needed with a larger percentage of $\mathrm{Cu}$ powder.
\end{abstract}

Keywords: SWH, PCM, paraffin wax, discontinuous discharging 


\section{Pendahuluan}

Penggunaan sistem pemanas untuk suplai air panas mencakup $75 \%$ dari konsumsi energi di perumahan, sektor komersial, dan industri [1]. Penggunaan sistem tersebut masih banyak yang menggunakan bahan bakar fosil [2]. Sumber daya bahan bakar fosil terbatas [3] sehingga diperlukan energi terbarukan yang sumbernya tidak terbatas [4]. Salah satu energi terbarukan yaitu tenaga surya [5]. Solar Water Heater merupakan perangkat yang memanfaatkan energi tersebut untuk memanaskan air [6]. Di sisi lain, penggunaan air memiliki kekurangan yaitu densitas yang tinggi sehingga memerlukan Phase Change Material $(P C M)$ berupa paraffin wax untuk mengurangi densitas yang tinggi pada air. Namun, penggunaan paraffin wax memiliki kekurangan yaitu nilai konduktivitas termal yang rendah [7] sehingga pada penelitian ini ditambahkan serbuk tembaga fraksi dengan fraksi berat $10 \%$. Penambahan serbuk tembaga diharapkan pada saat proses discharging dan charging akan lebih cepat.

Penelitian sebelumnya tentang nanofluid yaitu dengan cara menambahkan tembaga fase-nano ke dalam Heat Transfer Fluid (HTF) konvensional, yaitu air. Hasil penelitian yang diinginkan berupa perbandingan konduktivitas termal sebelum dan setelah penambahan tembaga fasa-nano. Hasil penelitian menunjukkan bahwa penambahan nanophase tembaga dapat menaikkan nilai konduktivitas termal dan mengurangi daya pertukaran panas secara signifikan [8].

Terdapat penelitian lain juga tentang penggunaan PCM campuran paraffin wax dengan nanomaterial aluminium oksida dan campuran paraffin wax dengan nanomaterial $\mathrm{CuO}$ atau copper oxide. Penelitian tersebut menggunakan paraffin wax tipe RT-18 dan nanomaterial yang digunakan berukuran $50 \mathrm{~nm}$. Hasil penelitian menyatakan bahwa waktu pelelehan campuran aluminium oksida dengan paraffin wax lebih lambat jika dibandingkan dengan campuran copper oxide dengan paraffin wax sehingga campuran paraffin wax dengan nanomaterial $\mathrm{CuO}$ lebih baik digunakan sebagai $P C M[9]$.

Penelitian lain yang sudah dilakukan juga dengan penambahan nanomaterial, tetapi hanya dengan campuran tembaga. Pada penelitian ini, nanomaterial Cu pada paraffin wax sebagai $P C M$, bertujuan menaikan nilai konduktivitas termal yang digunakan untuk tangki Thermal Energy Storage (TES) Nanomaterial $\mathrm{Cu}$ ini menggunakan ukuran $20 \mathrm{~nm}$ dan memiliki beberapa fraksi, yaitu $0.5 \%, 1 \%, 1.5 \%$, dan $2 \%$. Hasil penelitian yaitu konduktivitas termal naik berturut-turut sebesar $14.0 \%, 23.9 \%, 42.5 \%$ dan $46.3 \%$ [10].

Penelitian ini menggunakan peralatan uji hasil pengembangan dari peralatan uji sebelumnya [11]. Pada tangki alat uji, ditambahkan kapsul tembaga yang berisi campuran paraffin wax dan serbuk tembaga mesh 200 dengan fraksi berat $10 \%$. Penelitian ini berfokus pada proses discharging secara bertahap yaitu pelepasan kalor oleh campuran $P C M$ setelah dipanaskan pada proses charging sebelumnya. Proses discharging dimulai setelah suhu air mencapai $70{ }^{\circ} \mathrm{C}$ hingga suhu bak air penampung mencapai suhu $35{ }^{\circ} \mathrm{C}$. Proses discharging dilakukan secara bertahap untuk mengetahui pengaruh kenaikan suhu air di dalam tangki saat proses tidak mengalirkan air. Hal ini tetap dilakukan karena meskipun sudah ditambahkan serbuk tembaga, konduktivitas termal campuran PCMserbuk tembaga masih di bawah konduktivitas termal air. Pada penelitian ini akan ditentukan laju penurunan suhu air dan campuran PCM serta laju pelepasan kalor air dan campuran PCM. 


\section{Metode}

Diagram alir proses penelitian ini dapat dilihat pada gambar 2.1 berikut.

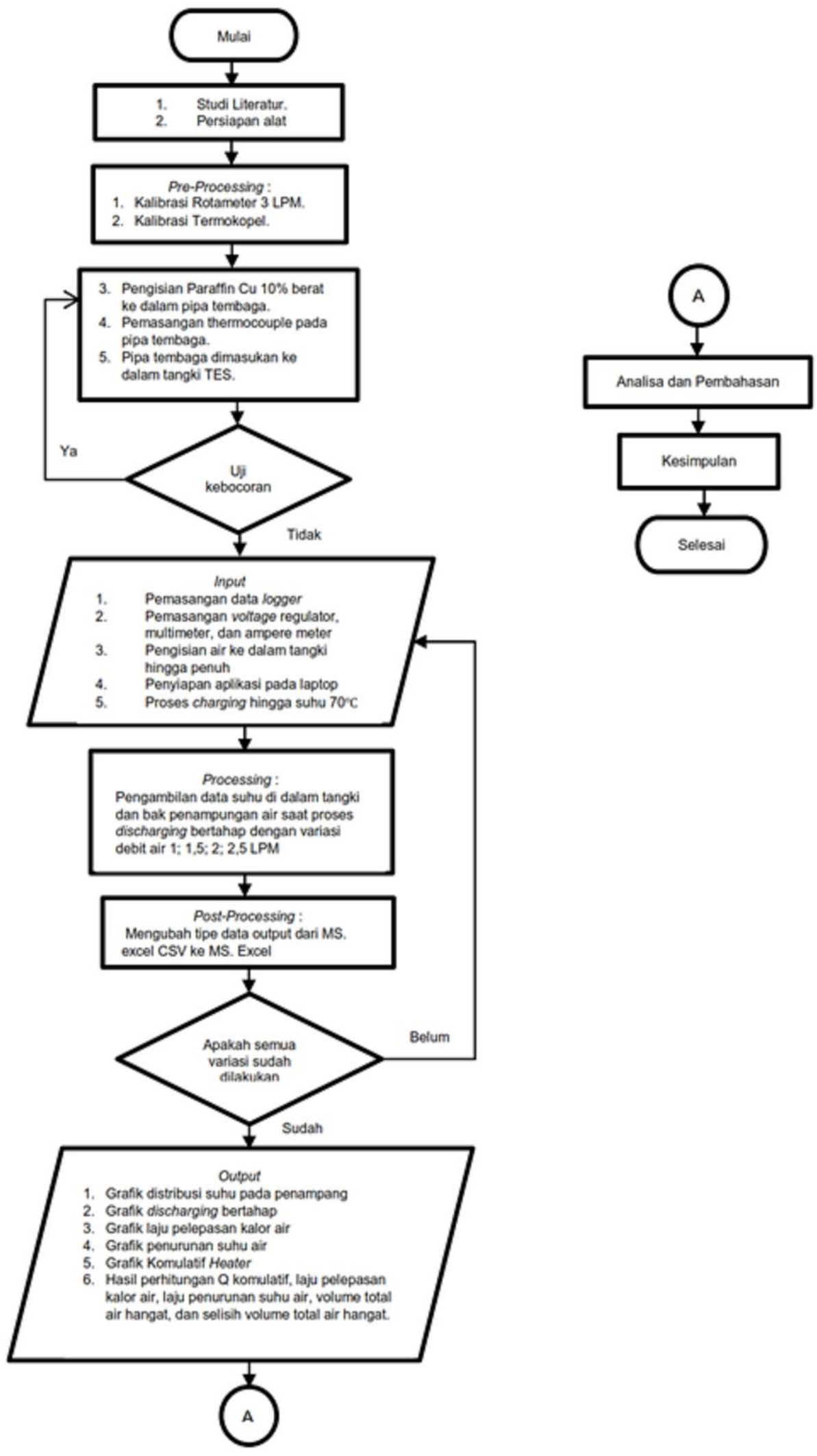

Gambar 2.1. Diagram Alir Penelitian 
Parameter yang digunakan pada penelitian ini yaitu variasi debit air $1 ; 1,5 ; 2$; dan 2 LPM. Pengambilan data pada penelitian ini dengan cara discharging bertahap. Setiap lima menit, air keran dibuka kemudian setelah lima menit ditutup. Pengambilan data dilakukan pada suhu di dalam tangki TES $70^{\circ} \mathrm{C}$ dan berakhir ketika suhu bak air penampung mencapai $35^{\circ} \mathrm{C}$. Data yang diambil saat proses discharging adalah suhu air pada tangki, suhu campuran PCM dalam tangki TES dan suhu air pada bak penampungan.

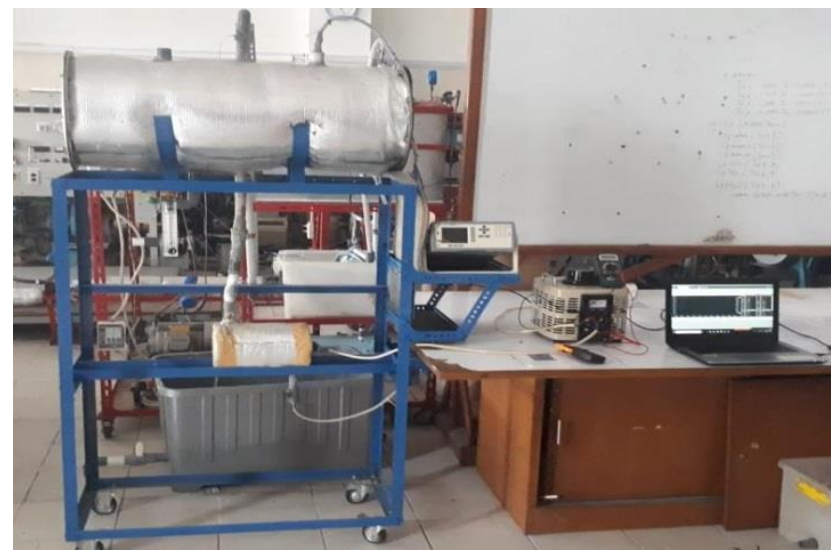

Gambar 2.2. Tangki TES

\subsection{Skema Penelitian}

Skema alat SWH pada gambar 2.3 merupakan skema proses discharging yang terdiri atas 1 katup inlet yang berfungsi sebagai masuknya aliran air keran ke tangki, 3 rotameter LZT M - 15 Instrument Company yang dapat mengukur debit sebesar 0,2 - 3,0 LPM serta 1 - 8 GPM LZT M - 15, 2 Tangki SWH yang berisi kapsul PCM didalamnya, 8 katup outlet yang berfungsi sebagai keluarnya air menuju ke bak pennampungan, dan 9 bak penampungan sebagai tempat menampunng air yang keluar dari tangki.

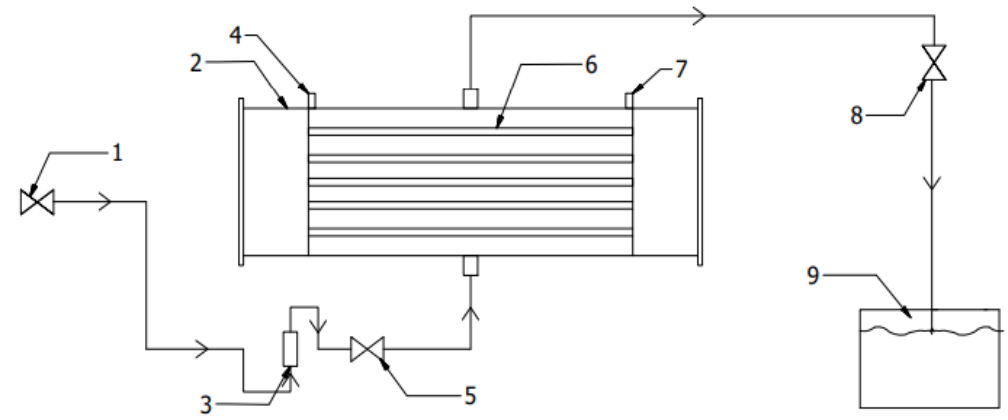

Gambar 2.3. Skema Proses Discharging Bertahap

Keterangan nomor pada Gambar 2.3:

(1) Keran air

(2) Tangki SWH

(3) Rotameter air

(4) Lubang pipa masuknya termokopel

(5) Katup masuknya air dari keran air ke tangki

(6) Tangki berisi pipa tembaga

(7) Lubang pipa masuknya termokopel

(8) Katup keluarnya air dari tangka ke bak air

(9) Bak penampung air

\subsection{Pemasangan Termokopel}

Pemasangan termokopel pada pipa tembaga dilakukan sebelum pengisian campuran paraffin wax - $\mathrm{Cu} 10 \%$ dengan mengebor pipa tembaga pada bagian yang sudah 
ditetapkan. Termokopel yang digunakan adalah termokopel tipe K. Letak pemasangan termocouple mengikuti gambar desain penempatan termocouple yang ditunjukan pada gambar 2.4
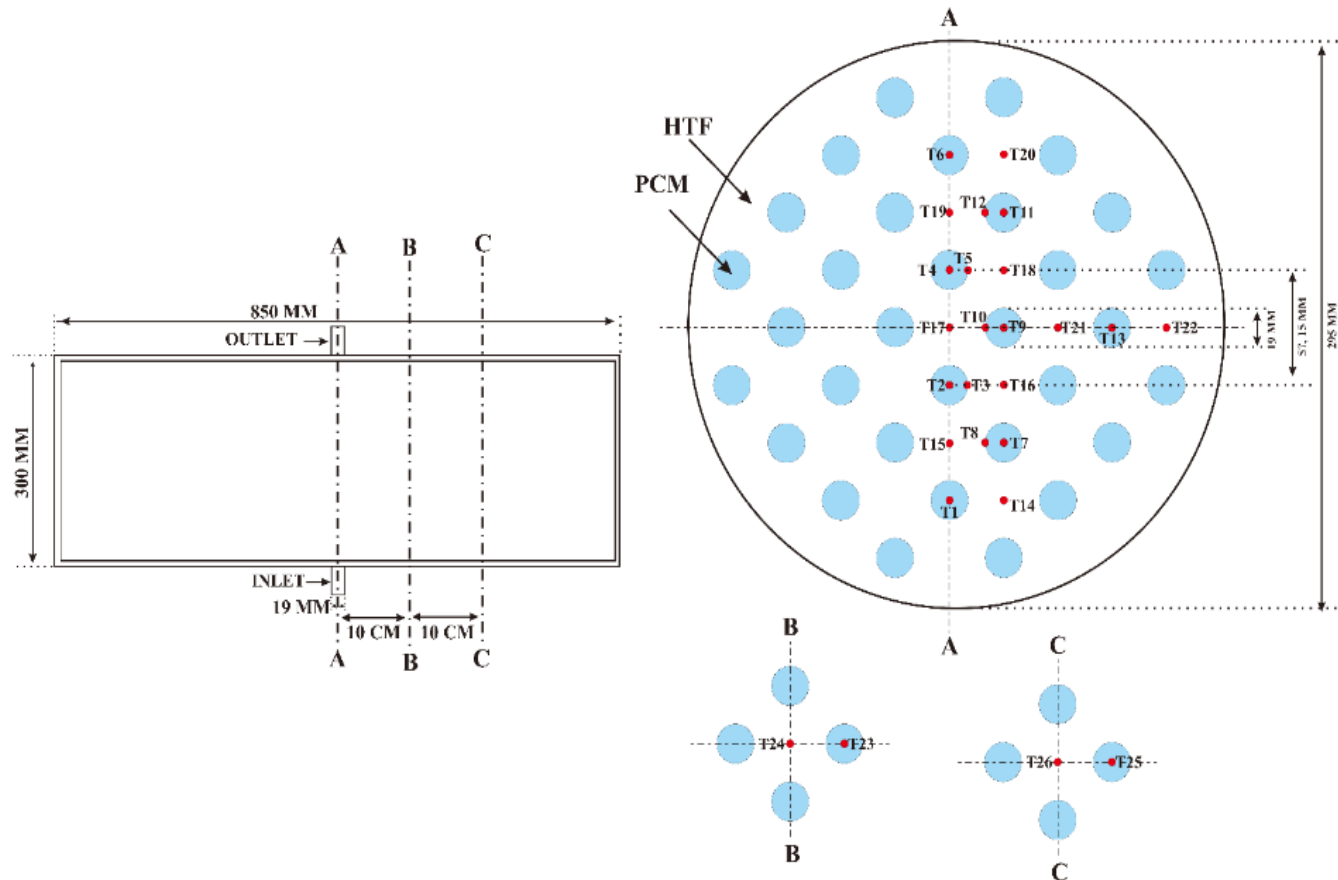

Gambar 2.4. Peletakan Termokopel

\section{Hasil dan Pembahasan}

\subsection{Evolusi Suhu Campuran PW + 10\% Cu dalam Arah Aksial}

Hasil setelah pengujian pada variasi 1 LPM arah aksial terdapat dua grafik yaitu evolusi suhu campuran paraffin wax dengan serbuk tembaga fraksi berat $10 \%$ dan evolusi suhu pada air. Grafik evolusi suhu pada campuran PCM dapat dilihat pada gambar 3.1 sedangkan grafik evolusi suhu air dapat dilihat pada gambar 3.2.

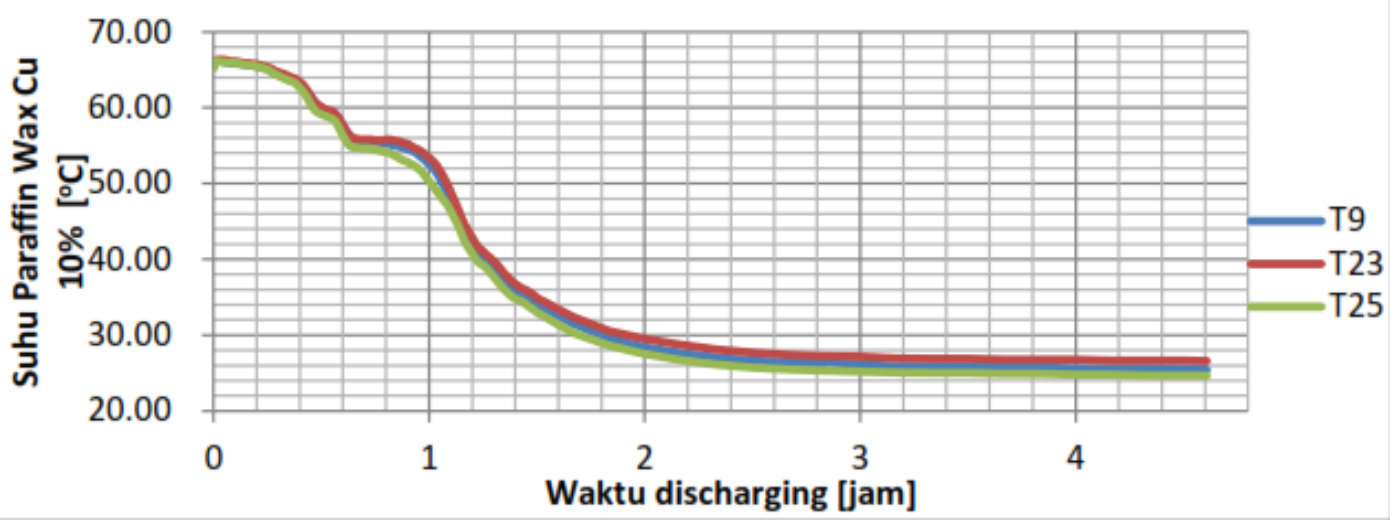

Gambar 3.1. Evolusi Suhu Campuran PW +10\% Cu dalam Arah Aksial

Grafik pada gambar 3.1. ditunjukkan bahwa suhu pada ketiga termokopel tidak mengalami kenaikan, tetapi pada 0,6-0,9 jam paraffin wax - Cu $10 \%$ sempat menahan suhu sekitar $55^{\circ} \mathrm{C}$. Peristiwa ini disebabkan terjadinya pelepasan kalor dari PCM ke HTF sehingga suhu HTF mengalami kenaikan saat air kran ditutup. Setelah 1 jam pengujian ketiga termokopel mengalami penurunan secara stabil karena fase paraffin wax berubah menjadi solid saat suhu mencapai $52,86^{\circ} \mathrm{C}$. 


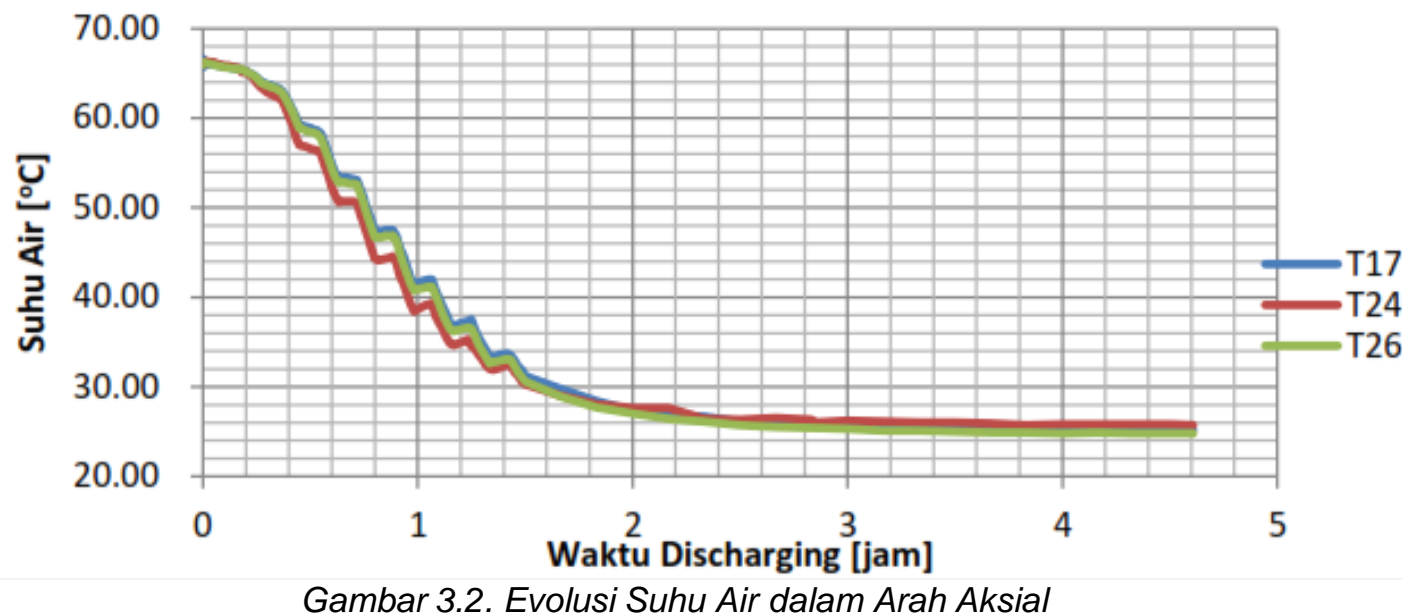

Grafik pada gambar 3.3. dalam arah aksial, suhu air cenderung mengalami kenaikan suhu secara bertahap daripada gambar 3.2. Naik turun grafik sangat dipengarungi oleh proses discharging bertahap saat air keran dimatikan dan dihidupkan. Naiknya suhu terjadi karena keran air ditutup sehingga air menyerap panas dari PCM. Setelah keran air ditutup, air menyerap panas dari $P C M$ sehingga saat keran dibuka suhu rata-rata mengalami kenaikan 1-2 ${ }^{\circ} \mathrm{C}$ pada waktu 0,6-1,4 jam dan setelah waktu 3-4,6 jam suhu dalam tangki konstan pada $25^{\circ} \mathrm{C}$ mengikuti suhu dari air keran.

Suhu pada ketiga termokopel dari 0-1,5 jam mengalami grafik naik turun karena terjadi pelepasan kalor dan setelah 1,5 jam, suhu dalam pipa cenderung lebih stabil tidak mengalami kenaikan karena campuran paraffin wax - $\mathrm{Cu} 10 \%$ berat sudah berubah fasa menjadi solid sempurna. Suhu pada ketiga termokopel dari 0-1,5 jam tidak mengalami perbedaan yang signifikan karena menggunakan debit air yang kecil.

\subsection{Evolusi Suhu Campuran PW $+10 \%$ Cu dalam Arah Vertikal}

Hasil pengujian pada variasi 1 LPM arah vertikal terdapat dua grafik yaitu evolusi suhu campuran paraffin wax dengan serbuk tembaga fraksi berat $10 \%$ dan evolusi suhu pada air. Grafik evolusi suhu pada campuran PCM dapat dilihat pada gambar 3.3, sedangkan grafik evolusi suhu air dapat dilihat pada gambar 3.4.

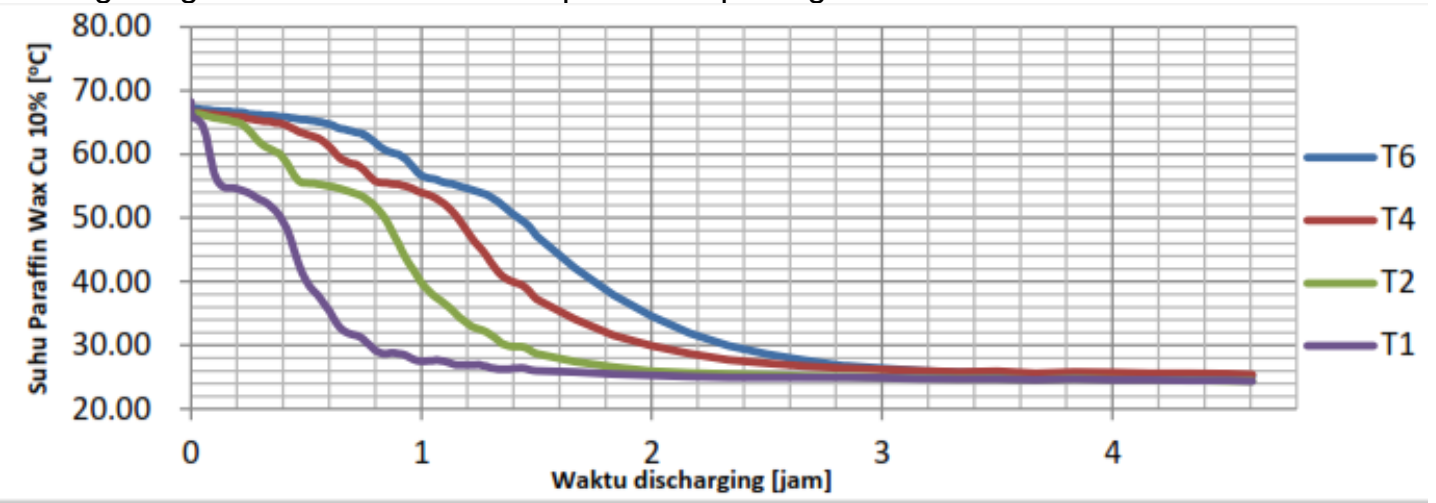

Gambar 3.3. Evolusi Suhu Campuran PW + 10\% Cu dalam Arah Vertikal

Suhu pada T1 ketika pengambilan data mengalami penurunan drastis daripada ketiga suhu termokopel lainnya (gambar 3.3). Rendahnya T1 dipengaruhi oleh letak pipa tembaga. Letak pipa tembaga berada pada paling dekat dengan input air keran masuk ke tangki TES. Sebaliknya, T6 memiliki suhu yang relatif konstan karena letak pipa tembaga yang paling jauh dari input air keran. Penurunan suhu T6 pada $0-1$ jam berkisar $11{ }^{\circ} \mathrm{C}$, suhu T4 berkisar $14^{\circ} \mathrm{C}$, suhu T2 berkisar $26^{\circ} \mathrm{C}$, dan suhu T1 pada $0-1$ jam berkisar $38^{\circ} \mathrm{C}$. Maka dari itu, penurunan suhu paling cepat terjadi pada T1 selama satu jam. 


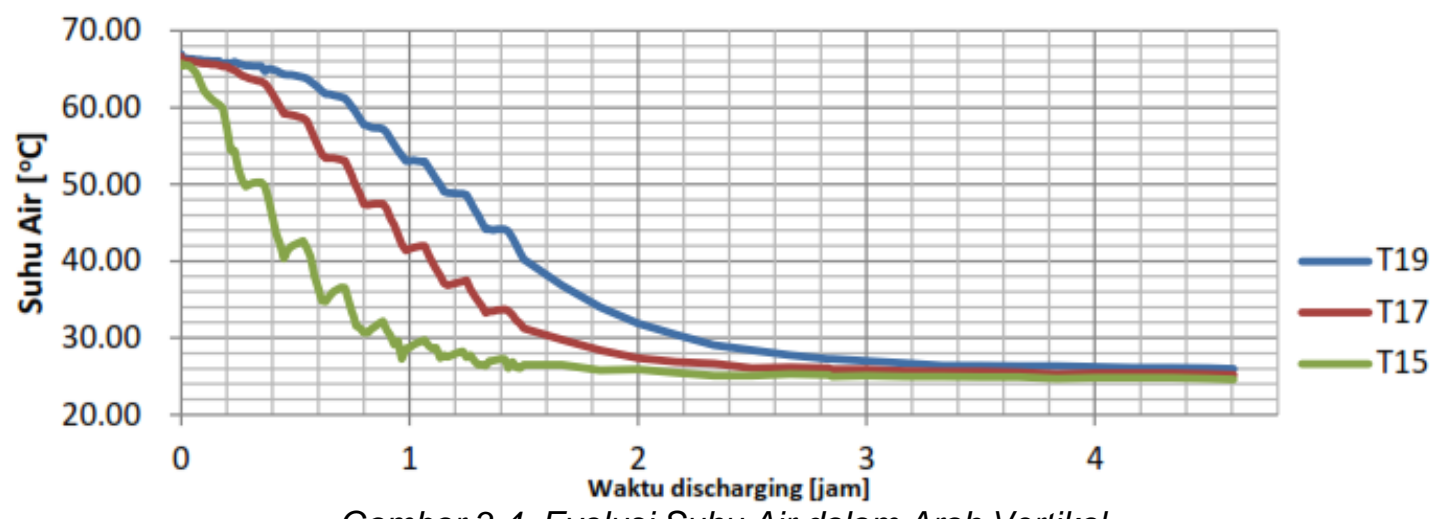

Gambar 3.4. Evolusi Suhu Air dalam Arah Vertikal

Suhu T15 mengalami penurunan drastis daripada ketiga termokopel lainnya dapat dilihat pada Gambar 3.4. Rendahnya T15 dipengaruhi oleh letak termokopel, letak T15 berada pada paling dekat dengan input air keran masuk ke tangki TES. Sebaliknya, T19 memiliki suhu yang relatif konstan karena letak yang paling jauh dari input air keran. Pada rentang waktu 0-1 jam, penurunan suhu T19 berkisar $14 \mathrm{C}$, penurunan suhu T17 berkisar $25^{\circ} \mathrm{C}$, dan penurunan suhu $\mathrm{T} 15$ berkisar $39^{\circ} \mathrm{C}$.

\subsection{Evolusi Suhu Campuran PW + 10\% Cu dalam Arah Horisontal}

Hasil pengujian pada variasi 1 LPM arah horisontal terdapat dua grafik yaitu evolusi suhu campuran paraffin wax dengan serbuk tembaga fraksi berat $10 \%$ dan evolusi suhu pada air. Grafik evolusi suhu pada campuran PCM dapat dilihat pada gambar 3.5, sedangkan grafik evolusi suhu air dapat dilihat pada gambar 3.6.

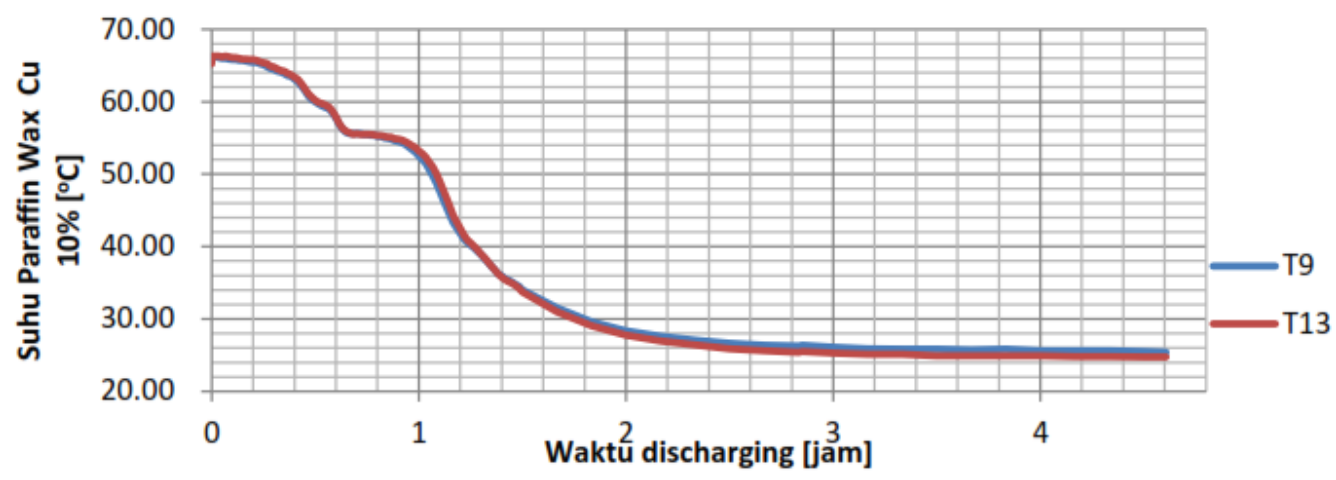

Gambar 3.5. Evolusi Suhu Campuran PW $+10 \%$ Cu dalam Arah Horisontal

Suhu pada kedua termokopel dari 0-1 jam tidak mengalami perbedaan yang signifikan karena menggunakan debit air yang kecil dan memiliki selisih suhu tidak sampai $1{ }^{\circ} \mathrm{C}$ dapat dilihat pada Gambar 3.5. Pada rentang waktu 0-1,5 jam, suhu T13 lebih tinggi dari T9, tetapi dari 1,5-4,5 jam T9 lebih tinggi dari T13. Suhu T9 pada awal pengambilan data lebih rendah dari T13 dikarenakan letak pipa tembaga T9 berada di atas output air keran sehingga saat keran dibuka T9 dahulu mengenai air dari T13 yang berada pada samping T9.

Grafik pada Gambar 3.5 menunjukkan bahwa suhu pada kedua termokopel tidak mengalami kenaikan, tetapi pada 0,6-0,9 jam campuran paraffin wax - $\mathrm{Cu} 10 \%$ sempat tertahan suhunya pada suhu sekitar $56^{\circ} \mathrm{C}$. Peristiwa ini diduga terjadi perubahan fase dari campuran paraffin wax dari fase cair menjadi fase padat. 


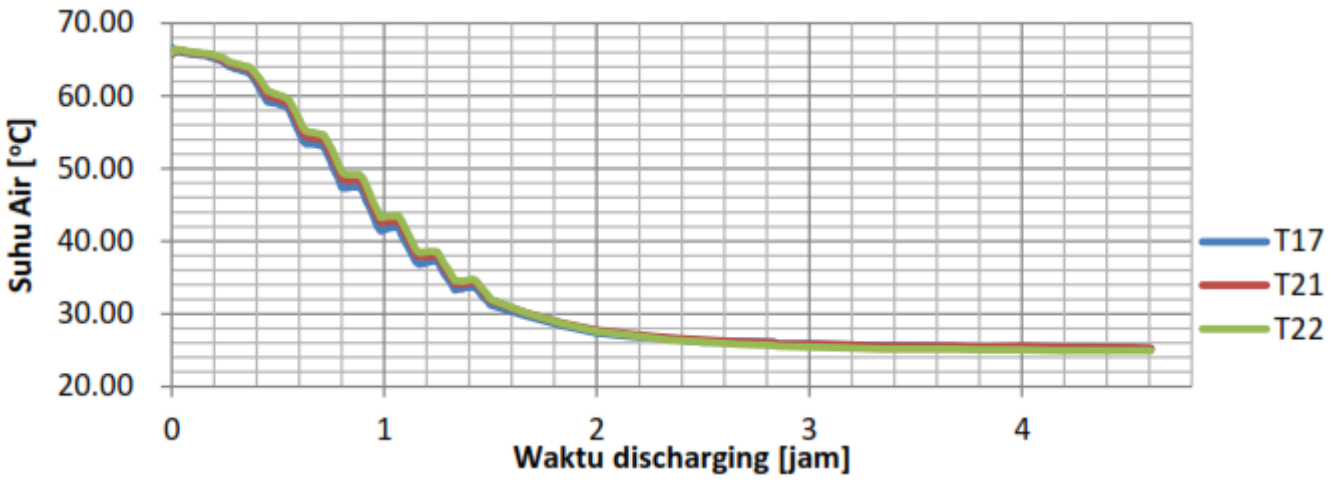

Gambar 3.6. Evolusi Suhu Air dalam Arah Horisontal

Grafik pada Gambar 3.6 menunjukkan bahwa suhu air arah horisontal cenderung terdapat kenaikan suhu daripada pada Gambar 3.5. Naik turun grafik sangat dipengaruhi oleh proses discharging bertahap saat air keran dimatikan dan dihidupkan. Naiknya suhu terjadi karena keran air ditutup sehingga air menyerap panas dari PCM. Kenaikan suhu terjadi dari 0,6-1,4 jam kemudian ketiga termokopel tidak mengalami kenaikan dan penurunan suhu stabil sampai selesai pengujian.

\subsection{Grafik Energi Kumulatif}

Energi kumulatif adalah energi yang dilepas saat proses discharging dari awal penelitian hingga selesai dan didapatkan dengan menggunakan Persamaan 1.

$Q_{\text {hum }}=43,13 \times 4180 \times(66,17-25,25)$

$$
Q_{\text {Rum }}=m \cdot c p \cdot \Delta T
$$

$Q_{\text {hum }}=7.377 .020,99 \mathrm{~J}$

Tabel 3.1 Energi Kumulatif (untuk debit air 1 LPM)

\begin{tabular}{ccccccc}
\hline \multirow{2}{*}{ Bahan } & $\mathrm{cp}$ & Massa & $\mathrm{T} 1$ & $\mathrm{~T} 2$ & $\Delta \mathrm{T}$ & Q kum \\
\cline { 2 - 7 } & {$[\mathrm{J} /(\mathrm{kg} . \mathrm{K})]$} & {$[\mathrm{kg}]$} & ${ }^{\circ} \mathbf{C}$ & ${ }^{\circ} \mathbf{C}$ & ${ }^{\circ} \mathbf{C}$ & $(\mathrm{J})$ \\
\hline Air & 4180 & 43.13 & 66.17 & 25.25 & 40.92 & $7,377,020.99$ \\
\hline Pipa Cu & 390 & 5.91 & 66.72 & 24.90 & 41.83 & $96,338.79$ \\
\hline PW+10\%Cu & 1839 & 6.7 & 66.14 & 25.05 & 41.09 & $1,029,378.78$ \\
\hline
\end{tabular}

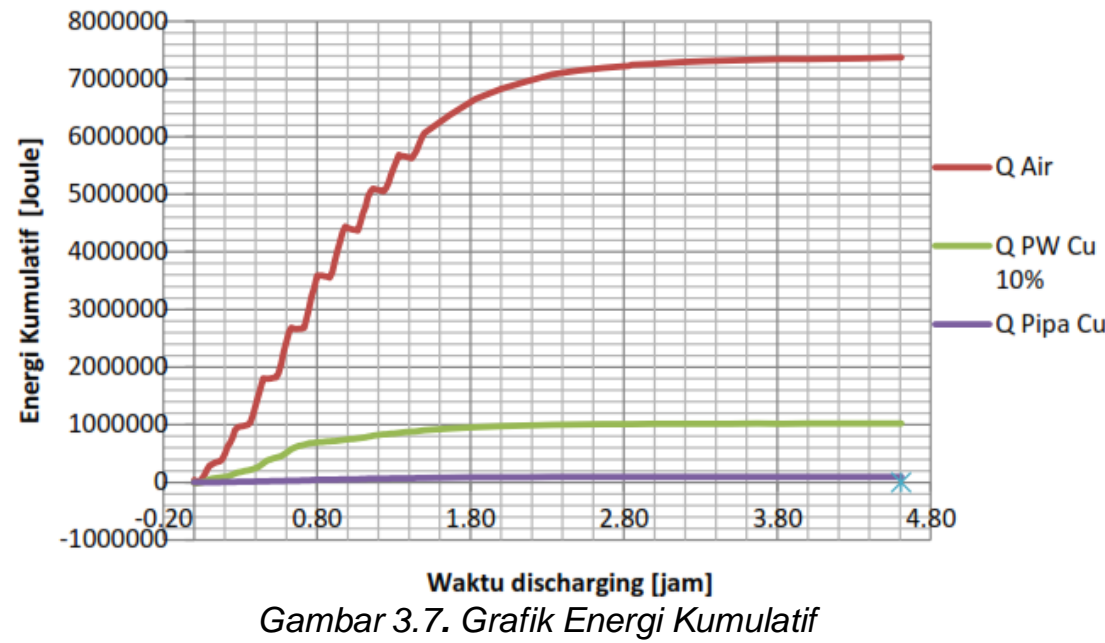

Grafik pada Gambar 3.7 kalor (Q) pipa Cu lebih rendah dari air dan campuran paraffin wax - Cu disebabkan nilai $\mathrm{Cp}$ yang rendah yaitu $390 \mathrm{~J} / \mathrm{kg} . \mathrm{K}$, sedangkan nilai $\mathrm{Cp}$ air 4180 
J/kg.K dan Cp Paraffin Wax - Cu $10 \% 2000$ J/kg.K. Grafik Q Paraffin Wax Cu 10\% mengalami kenaikan signifikan pada 0-0,6 jam sebanyak 5-10 kJ, setelah 0,6 jam laju kenaikan hanya sebesar 2-3 kJ dan relatif stabil. Grafik Q pipa $\mathrm{Cu}$ mengalami kenaikan relatif stabil sebesar $0,1-0,3 \mathrm{~kJ}$. Kenaikan grafik paling signifikan terjadi pada $\mathrm{Q}$ air pada 0 1,8 jam sebesar 70-80 kJ, setelah 1,8 jam relatif mengalami kenaikan lebih stabil.

\subsection{Laju Pelepasan Kalor dan Laju Penurunan Suhu}

\subsubsection{Laju Pelepasan Kalor Air}

Laju pelepasan kalor pada air dapat dicari dengan persamaan 2:

$$
\begin{aligned}
& Q=\frac{Q_{\text {humwulntif }}}{t_{\text {temtal }}} \\
& Q=\frac{7.977 .020,99}{16.585}=444,8 \frac{\mathrm{J}}{\mathrm{g}}
\end{aligned}
$$

Tabel 3.2. Laju Pelepasan Kalor Air

\begin{tabular}{cccccccc}
\hline $\mathrm{V}$ & $\mathrm{T} 1$ Air & T2 Air & $\Delta \mathrm{T}$ & $\Delta \mathrm{t}$ & Q kum Air & $\begin{array}{c}\text { Q Paraffin Cu } \\
10 \%\end{array}$ & $\ell$ \\
\hline LPM & ${ }^{\circ} \mathbf{C}$ & ${ }^{\circ} \mathbf{C}$ & ${ }^{\circ} \mathbf{C}$ & (detik) & $(\mathrm{J})$ & $(\mathrm{J})$ & $(\mathrm{J} / \mathrm{s})$ \\
\hline $\mathbf{1}$ & 66.17 & 25.25 & 40.92 & 16585 & $7,377,020.99$ & $1,029,378.78$ & 444.80 \\
\hline $\mathbf{1 . 5}$ & 66.85 & 28.15 & 38.69 & 14825 & $6,975,258.37$ & $994,180.17$ & 470.51 \\
\hline $\mathbf{2}$ & 63.07 & 26.24 & 36.84 & 8405 & $6,641,135.76$ & $835,264.46$ & 790.14 \\
\hline $\mathbf{2 . 5}$ & 65.09 & 26.03 & 39.06 & 9690 & $7,040,438.55$ & $982,907.99$ & 726.57 \\
\hline
\end{tabular}

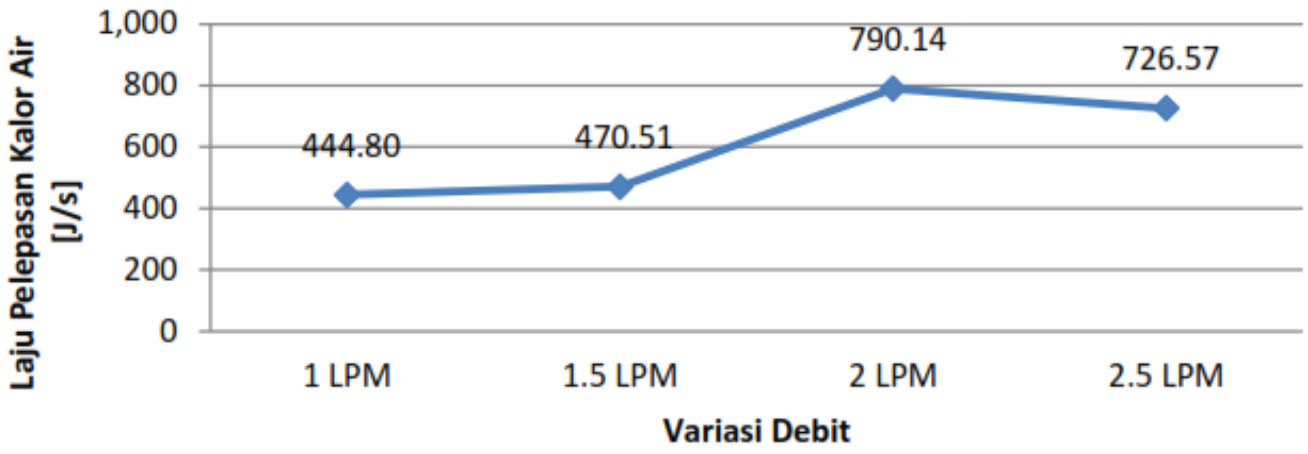

Gambar 3.8. Laju Pelepasan Kalor Air

Grafik pada gambar 3.8 di atas ditunjukan bahwa laju pelepasan kalor air paling rendah yaitu pada variasi 1 LPM yaitu 444,8 J/s karena memiliki waktu yang paling lama 4,5 jam di antara variasi lainnya, sedangkan laju pelepasan terbesar pada variasi $2 L P M$ yaitu 790,14 $\mathrm{J} / \mathrm{s}$ karena memiliki waktu yang tercepat saat pengujian. Variasi 2 LPM memiliki waktu yang tercepat karena suhu mulai proses discharging di bawah $65^{\circ} \mathrm{C}$ yang membuat proses penurunan lebih cepat dari variasi yang suhu awalnya $69^{\circ} \mathrm{C}$. Pengambilan data pada variasi $2 L P M$ mencapai 2,4 jam dan variasi 2 LPM memiliki perubahan suhu paling rendah daripada ketiga variasi lainnya.

\subsubsection{Laju Pelepasan Kalor Paraffin Wax + Cu 10\% Berat}

Laju pelepasan kalor pada campuran paraffin wax $\mathrm{Cu} 10 \%$ dapat dicari dengan persamaan 2. 


$$
\begin{aligned}
& \phi=\frac{Q_{\text {lumwlmiff }}}{t_{\text {toinal }}} \\
& Q=\frac{1.029 .978,78}{16.585}=62,07 \frac{I}{g}
\end{aligned}
$$

\begin{tabular}{|c|c|c|c|c|c|c|c|}
\hline V & $\begin{array}{c}\text { T1 } \\
\text { PCM }\end{array}$ & $\begin{array}{c}\text { T2 } \\
\text { PCM }\end{array}$ & $\Delta \mathrm{T}$ & $\Delta \mathrm{t}$ & Q kum Air & $\begin{array}{c}\text { Q Paraffin Cu } \\
10 \%\end{array}$ & $Q$ \\
\hline LPM & ${ }^{\circ} \mathrm{C}$ & ${ }^{\circ} \mathrm{C}$ & ${ }^{\circ} \mathrm{C}$ & (detik) & $(\mathrm{J})$ & (J) & $(\mathrm{J} /$ \\
\hline 1 & 66.14 & 25.05 & 41.09 & 16585 & $7,377,020.99$ & $1,029,378.78$ & 62.07 \\
\hline 1.5 & 66.14 & 27.95 & 38.20 & 14825 & $6,975,258.37$ & $994,180.17$ & 67.06 \\
\hline 2 & 62.50 & 26.07 & 36.43 & 8405 & $6,641,135.76$ & $835,264.46$ & 99.38 \\
\hline 2.5 & 65.44 & 25.92 & 39.52 & 9690 & $7,040,438.55$ & $982,907.99$ & 101.44 \\
\hline
\end{tabular}

Tabel 3.3. Laju Pelepasan Kalor Paraffin Wax Cu 10\%

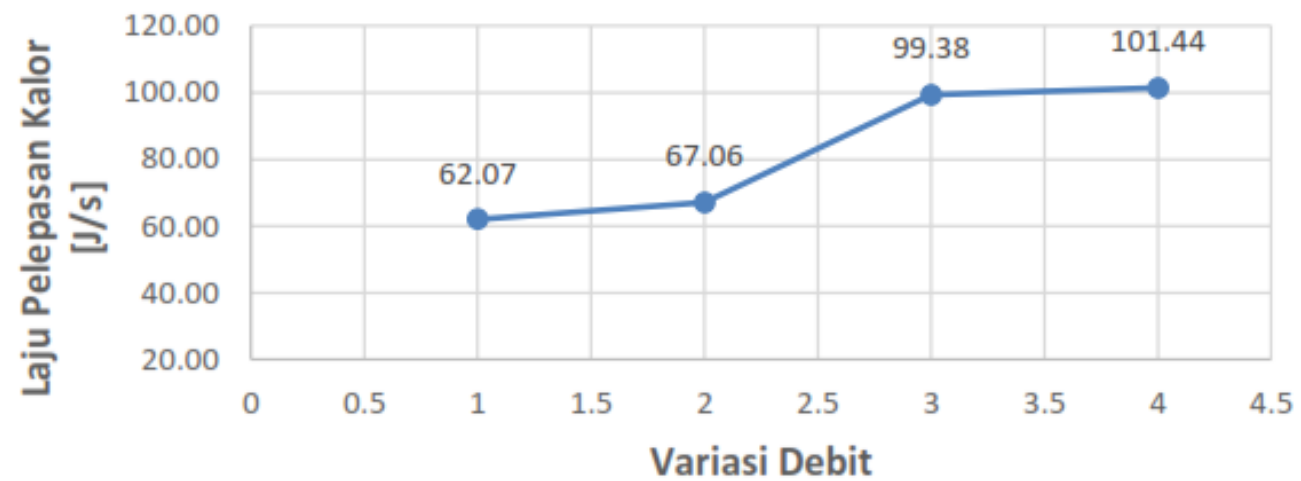

Gambar 3.9. Laju Pelepasan Kalor Paraffin Wax + Cu 10\%

Grafik pada gambar 3.9 di atas ditunjukkan bahwa laju pelepasan kalor pada campuran paraffin wax - Cu 10\% paling rendah yaitu pada variasi 1 LPM yaitu 62,07 J/s. Sedangkan laju pelepasan terbesar pada variasi 2,5 LPM yaitu 101,44 J/s. Pada variasi debit air 2,5 LPM, laju pelepasan kalor terbesar karena menggunakan debit paling besar yang mengakibatkan perubahan suhu yang cepat sehingga mengalami pelepasan kalor terbesar, yaitu 101,44 Joule per detik.

\subsubsection{Laju Penurunan Suhu Air}

Laju penurunan suhu pada air dapat dicari dengan Persamaan 3.

$$
\begin{aligned}
& \text { Laju Penurunan Suhu Air }=\frac{T T_{\text {med }}-T_{\text {mini }}}{} \\
& \text { Laju Penurunon Suhu Air }=\frac{[66.17-25.25) \times 3600}{16.58 .5}=8,88 \frac{{ }^{\circ} \mathrm{C}}{\text { finm }}
\end{aligned}
$$

Tabel 3.4. Laju Penurunan Suhu Air

\begin{tabular}{cccccccc}
\hline $\mathrm{V}$ & T1 Air & T2 Air & $\Delta \mathrm{T}$ & $\Delta \mathrm{t}$ & Q kum Air & $\begin{array}{c}\text { Q Paraffin } \\
\mathrm{Cu}\end{array}$ & Q pipa Cu \\
\hline LPM & ${ }^{\circ} \mathbf{C}$ & ${ }^{\circ} \mathbf{C}$ & ${ }^{\circ} \mathbf{C}$ & (detik) & ( & ( & $(\mathrm{J})$ \\
\hline $\mathbf{1}$ & 66.17 & 25.25 & 40.92 & 16585 & $7,377,020.9$ & $1,029,378.78$ & $96,338.79$ \\
\hline $\mathbf{1 . 5}$ & 66.85 & 28.15 & 38.69 & 14825 & $6,975,258.3$ & $994,180.17$ & $90,554.78$ \\
\hline $\mathbf{2}$ & 63.07 & 26.24 & 36.84 & 8405 & $6,641,135.7$ & $835,264.46$ & $85,688.62$ \\
\hline $\mathbf{2 . 5}$ & 65.09 & 26.03 & 39.06 & 9690 & $7,040,438.5$ & $982,907.99$ & $89,915.17$ \\
\hline
\end{tabular}




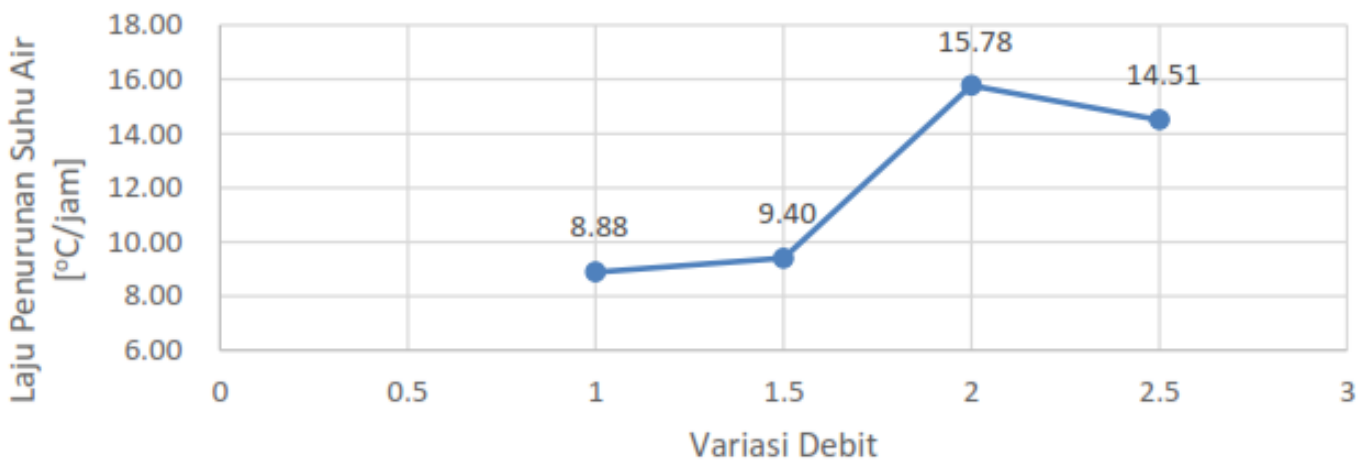

Gambar 3.10. Laju Penurunan Suhu Air

Grafik pada Gambar 3.10 di atas menunjukan bahwa laju penurunan suhu air paling rendah $8,88^{\circ} \mathrm{C} / \mathrm{jam}$ yaitu pada variasi $1 L P M$ karena memiliki waktu yang paling lama 4,5 jam diantara variasi lainnya, sedangkan laju penurunan suhu air terbesar $15,78{ }^{\circ} \mathrm{C} / \mathrm{jam}$ pada variasi $2 L P M$ karena memiliki waktu yang tercepat saat pengujian. Variasi 2 LPM memiliki waktu yang tercepat karena suhu mulai proses discharging di bawah $65 \mathrm{C}$ yang membuat proses penurunan lebih cepat dari variasi yang suhu awalnya $69^{\circ} \mathrm{C}$. Pengambilan data pada variasi $2 L P M$ mencapai 2,4 jam. Oleh karena itu, pada 2 LPM mengalami rata-rata penurunan suhu $15,78^{\circ} \mathrm{C}$ dalam setiap jam dan pada 1 LPM mengalami rata-rata penurunan suhu $8,88^{\circ} \mathrm{C}$ dalam setiap jam.

\subsubsection{Laju Penurunan Suhu Paraffin Wax + Cu $10 \%$ Berat}

Laju penurunan suhu pada paraffin wax $\mathrm{Cu} 10 \%$ dapat dicari dengan persamaan 3 .

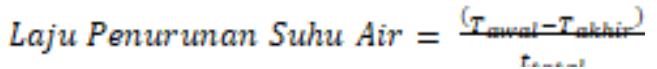

$$
\begin{aligned}
& \text { Laju Penurunan Suhu Air }=\frac{(66,14-25,05) \times 3600}{16585}=8,92 \frac{{ }^{\circ} \mathrm{C}}{\text { inm }}
\end{aligned}
$$

Tabel 3.5. Laju Penurunan Suhu Paraffin Wax Cu 10\%

\begin{tabular}{cccccccc}
\hline $\mathrm{V}$ & $\begin{array}{c}\mathrm{T} 1 \\
\mathrm{PCM}\end{array}$ & $\begin{array}{c}\mathrm{T} 2 \\
\mathrm{PCM}\end{array}$ & $\Delta \mathrm{T}$ & $\Delta \mathrm{t}$ & Q kum Air & $\begin{array}{c}\text { Q Paraffin } \mathrm{Cu} \\
10 \%\end{array}$ & Q pipa Cu \\
\hline LPM & ${ }^{\circ} \mathbf{C}$ & ${ }^{\circ} \mathbf{C}$ & ${ }^{\circ} \mathbf{C}$ & (detik) & $(\mathrm{J})$ & $(\mathrm{J})$ & ( \\
\hline $\mathbf{1}$ & 66.14 & 25.05 & 41.09 & 16585 & $7,377,020.99$ & $1,029,378.78$ & $96,338.79$ \\
\hline $\mathbf{1 . 5}$ & 66.14 & 27.95 & 38.20 & 14825 & $6,975,258.37$ & $994,180.17$ & $90,554.78$ \\
\hline $\mathbf{2}$ & 62.50 & 26.07 & 36.43 & 8405 & $6,641,135.76$ & $835,264.46$ & $85,688.62$ \\
\hline $\mathbf{2 . 5}$ & 65.44 & 25.92 & 39.52 & 9690 & $7,040,438.55$ & $982,907.99$ & $89,915.17$ \\
\hline
\end{tabular}

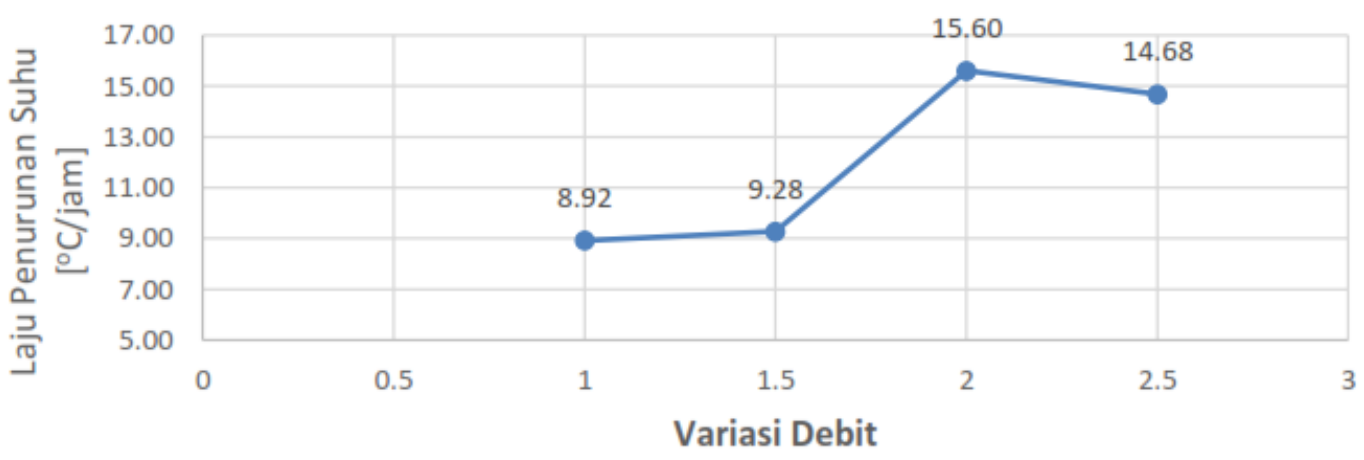

Gambar 3.11. Laju Penurunan Suhu Paraffin Wax Cu 10\% 
Grafik pada Gambar 3.11 di atas menunjukan bahwa laju penurunan suhu paraffin wax $\mathrm{Cu} 10 \%$ paling rendah $8,92 \mathrm{C} / \mathrm{jam}$ yaitu pada variasi 1 LPM karena memiliki waktu yang paling lama 4,5 jam diantara variasi lainnya, sedangkan laju penurunan suhu air terbesar $15,6^{\circ} \mathrm{C} / \mathrm{jam}$ pada variasi 2 LPM karena memiliki waktu yang tercepat saat pengujian. Variasi 2 LPM memiliki waktu yang tercepat karena suhu mulai proses discharging di bawah $65^{\circ} \mathrm{C}$ yang membuat proses penurunan lebih cepat dari variasi yang suhu awalnya $69^{\circ} \mathrm{C}$. Pengambilan data pada variasi $2 L P M$ mencapai 2,4 jam. Oleh karena itu, pada 2 LPM mengalami rata-rata penurunan suhu $15,6^{\circ} \mathrm{C}$ dalam setiap jam dan pada 1 LPM mengalami rata-rata penurunan suhu $8,92^{\circ} \mathrm{C}$ dalam setiap jam.

\section{KesimpUlan}

Pengukuran laju pelepasan kalor secara bertahap pada tangki solar water heater dengan variasi campuran paraffin wax dan serbuk tembaga $10 \%$ berat pada debit air 1 ; 1,$5 ; 2$ \& 2,5 LPM telah dilakukan. Kesimpulan dari penelitian ini adalah semakin besar debit air, semakin besar pula laju penurunan suhu air. Laju penurunan suhu air paling besar terjadi pada debit air 2 LPM yaitu sebesar $15,78^{\circ} \mathrm{C} /$ jam. Semakin besar debit air, semakin besar pula laju penurunan suhu campuran paraffin wax - serbuk $\mathrm{Cu} 10 \%$ berat. Laju penurunan suhu campuran paraffin wax - serbuk Cu 10\% berat terjadi pada debit air 2 LPM yaitu sebesar $15,6{ }^{\circ} \mathrm{C} / j a m$. Semakin besar debit air, semakin besar pula laju pelepasan kalor air. Laju pelepasan kalor air paling tinggi terjadi pada debit air 2 LPM yaitu sebesar $790,14 \mathrm{~J} / \mathrm{s}$. Semakin besar debit air, semakin besar pula laju pelepasan kalor campuran paraffin wax - serbuk Cu $10 \%$ berat. Laju pelepasan kalor campuran paraffin wax - serbuk Cu 10\% berat terjadi pada debit air 2,5 LPM yaitu sebesar 101,44 J/s.

\section{Daftar Pustaka}

[1] M. K. A. Sharif et al., "Review of the application of phase change material for heating and domestic hot water systems," Renew. Sustain. Energy Rev., vol. 42, pp. 557-568, 2015, doi: 10.1016/j.rser.2014.09.034.

[2] H. Al-Madani, "The performance of a cylindrical solar water heater," Renew. Energy, vol. 31, no. 11, pp. 1751-1763, 2006, doi: 10.1016/j.renene.2005.09.010.

[3] H. Sasana and I. Ghozali, "The impact of fossil and renewable energy consumption on the economic growth in Brazil, Russia, India, China and South Africa," Int. J. Energy Econ. Policy, vol. 7, no. 3, pp. 194-200, 2017.

[4] V. Ş. Ediger and E. Kentel, "Renewable energy potential as an alternative to fossil fuels in Turkey," Energy Convers. Manag., vol. 40, no. 7, pp. 743-755, 1999, doi: 10.1016/S0196-8904(98)00122-8.

[5] J. Zucchetto and S. Brown, "Comparison of the fossil fuel energy requirements for solar, natural gas, and electrical water heating systems," Resour. Recover. Conserv., vol. 2, no. 4, pp. 283-300, 1977, doi: 10.1016/0304-3967(77)90019-1.

[6] J. Han, A. P. J. Mol, and Y. Lu, "Solar water heaters in China: A new day dawning," Energy Policy, vol. 38, no. 1, pp. 383-391, 2010, doi: 10.1016/j.enpol.2009.09.029.

[7] T. Watanabe and A. Kanzawa, "Second law optimization of a latent heat storage system with PCMS having different melting points," Heat Recover. Syst. CHP, vol. 15, no. 7, pp. 641-653, 1995, doi: 10.1016/0890-4332(95)90044-6.

[8] U. S. C. Stephen and A. E. Jeffrey, "Enhancing Thermal Conductivity of Fluids with Nanoparticles," J. Chem. Eng. Data, vol. 8, no. 3, pp. 281-285, 1995, doi: 10.1021/je60018a001.

[9] M. A. Alomair, Y. A. Alomair, H. A. Abdullah, S. Mahmud, and S. Tasnim, "Nanoparticle Enhanced Phase Change Material in Latent Heat Thermal Energy Storage System: An Experimental Study," Proc. Int. Conf. Energy Harvest. Storage, Transf., no. 119, pp. 15, 2017, doi: 10.11159/ehst17.119.

[10] S. C. Lin and H. H. Al-Kayiem, "Evaluation of copper nanoparticles - Paraffin wax compositions for solar thermal energy storage," Sol. Energy, vol. 132, pp. 267-278, 2016, doi: 10.1016/j.solener.2016.03.004.

[11] M. Nadjib, "Penggunaan Paraffin Wax Sebagai Penyimpan Kalor Pada Pemanas Air 
Tenaga Matahari Thermosyphon," Rotasi, vol. 18, no. 3, p. 76, 2016, doi: 10.14710/rotasi.18.3.76-85. 